\title{
Determinan Kejadian Bayi Berat Lahir Rendah (BBLR) Di Rs Kencana Serang Banten Tahun 2019
}

\author{
Yuda Muhara Sari \\ Universitas Respati Indonesia \\ Email : yudanathan@gmail.com
}

\begin{abstract}
Abstrak
Bayi Berat Lahir Rendah (BBLR) diartikan sebagai bayi yang lahir dengan berat badan kurang dari 2500 gram . Secara keseluruhan, diperkirakan 15\% - 20\% dari seluruh kelahiran di dunia mengalami berat badan lahir rendah, yang mewakili lebih dari 20 juta kelahiran per tahun . Prevalensi BBLR di Indonesia dari tahun 2007 (11,5\%) hingga tahun 2013 (10,2\%) terjadi penurunan namun lambat dalam 7 tahun terakhir, sedangkan angka kejadian BBLR di RS Kencana Serang Banten Tahun 2019 sebesar 11,4\% . Tujuan penelitian ini adalah Diketahui Determinan kejadian BBLR di RS Kencana Serang Banten Tahun 2019. Rancangan penelitian Cross Sectional, sampel dalam penelitian ini berjumlah 179 responden. Analisis dilakukan secara univariate, bivariate menggunakan chi square dan multivariate menggunakan regresi logistic ganda. Variabel yang berhubungan dengan kejadian BBLR pada ibu bersalin adalah usia $(p=0,000)$, pendidikan $(p=0,000)$, pekerjaan $(p=0,004)$ dan kunjungan ANC $(p=0,000)$ sedangkan variabel yang tidak berhubungan adalah paritas $(p=0,540)$. Variabel yang dominan berhubungan dengan kejadian BBLR pada ibu bersalin adalah kunjungan ANC dengan Odds ratio (OR) 18,4. Pihak Rumah Sakit mengoptimalkan pelayanan antenatal secara komprehensif, terpadu dan berkualitas agar adanya masalah kesehatan atau penyakit penyerta kehamilan dapat dideteksi dan ditangani secara dini
\end{abstract}

Kata Kunci : Bayi Berat Lahir Rendah, antenatal care

\section{Abstract}

Low birth weight babies (LBW) are defined as babies born weighing less than 2500 grams. Overall, it is estimated that $15 \%-20 \%$ of all births in the world are low birth weight, which represents more than 20 million births per year. . The prevalence of LBW in Indonesia from 2007 $(11.5 \%)$ to $2013(10.2 \%)$ has decreased but slowly in the last 7 years, while the incidence of LBW at Kencana Hospital Serang Banten in 2019 was $11.4 \%$. The purpose of this study was to know the determinants of LBW incidence in RS Kencana Serang Banten in 2019. Cross sectional research design, the sample in this study amounted to 179 respondents. The analysis was performed univariate, bivariate using chi square and multivariate using multiple logistic regression. The variables that were related to the incidence of LBW at birth were age $(p=0,000)$, education $(p=0,000)$, occupation $(p=0.004)$ and ANC visits $(p=0,000)$, while the unrelated variable was parity $(p=0.540)$. . The dominant variable associated with the incidence of LBW in labor was ANC visit with an odds ratio (OR) of 18.4. The hospital optimizes antenatal services in a comprehensive, integrated and quality manner so that health problems or pregnancy comorbidities can be detected and treated early.

Keyword : low birth weight, antenatal care

http://ejournal.urindo.ac.id/index.php/kesehatan 


\section{PENDAHULUAN}

Bayi Berat Lahir Rendah (BBLR) diartikan sebagai bayi yang lahir dengan berat badan kurang dari 2500 gram. BBLR merupakan prediktor tertinggi angka kematian bayi, terutama dalam satu bulan pertama kehidupan. Berdasarkan studi epidemiologi, BBLR mempunyai risiko kematian 20 kali lipat lebih besar di bandingkan dengan bayi yang lahir dengan berat badan normal (Kosim dkk, 2012) .

BBLR selalu menjadi masalah kesehatan masyarakat yang signifikan secara global dan berhubungan dengan berbagai konsekuensi jangka pendek maupun jangka panjang . Secara keseluruhan, diperkirakan 15\% - 20\% dari seluruh kelahiran di dunia mengalami bayi berat lahir rendah, yang mewakili lebih dari 20 juta kelahiran per tahun .

WHO dan UNICEF (2013) menyatakan bahwa terjadi peningkatan kejadian BBLR (periode 2009-2013) dari 15,5\% menjadi $16 \%$ dan sebesar 95,6\% dari jumlah tersebut berada di negara berkembang. Prevalensi BBLR di Indonesia dari tahun 2007 (11,5\%) hingga tahun $2013(10,2 \%)$ terjadi penurunan namun lambat dalam 7 tahun terakhir (Kemenkes RI, 2014), dan sebagian besar bayi BBLR yang meninggal pada masa neonatus adalah bayi dengan berat lahir <2.500 gram (Depkes, 2013) .

Beberapa penyebab terjadinya BBLR diantaranya adalah ibu hamil mengalami
Kekurangan Energi Kronis (KEK), mengalami anemia, kurangnya suplai zat gizi ibu hamil, komplikasi kehamilan, paritas ibu dan jarak kelahiran. BBLR membutuhkan penanganan serius, karena pada kondisi tersebut bayi mudah mengalami hipotermi dan belum sempurna pembentukan organ tubuhnya sehingga rentan mengalami kematian (Proverawati, 2010) .

BBLR juga dapat dipengaruhi oleh status anemia ibu hamil. Kelompok ibu hamil merupakan salah satu kelompok yang berisiko tinggi mengalami anemia, yang berdampak pada gangguan nutrisi dan oksigenasi utero plasenta. Hal ini menimbulkan gangguan pertumbuhan hasil konsepsi, terjadi immaturitas, prematuritas, cacat bawaan, atau janin lahir dengan BBLR (Soeharyo, 1999) . Prevalensi anemia defisiensi besi masih tergolong tinggi yaitu sekitar 30\% lebih dari populasi manusia di dunia yang terdiri dari anak-anak, wanita menyusui, wanita usia subur dan wanita hamil (WHO, 2011) . Faktor-faktor lain pada ibu hamil yang rentan melahirkan bayi BBLR yaitu, umur ibu hamil, paritas ibu, jarak persalinan, tinggi badan ibu, hipertensi, pre eklamsi/eklamsi, kelainan letak janin, riwayat obstetri buruk, dan penyakit kronis yang diderita ibu, serta masalah lainnya .

Stanford Children's Health (2016) merumuskan beberapa faktor lain yang dapat mempengaruhi terjadinya BBLR yaitu usia, ibu remaja (terutama yang lebih muda dari 15 tahun) memiliki risiko 
lebih tinggi melahirkan bayi dengan berat lahir rendah . Lebih dari setengah dari bayi kembar dan kelipatan kelahiran lainnya memiliki berat lahir rendah. Kesehatan ibu, bayi dari ibu yang terpapar obat-obatan terlarang, alkohol, dan rokok lebih cenderung memiliki berat lahir rendah . Ibu dari status sosial ekonomi rendah juga lebih cenderung memiliki nutrisi yang lebih sedikit semasa kehamilan. Perawatan prenatal yang tidak memadai dan komplikasi kehamilan juga merupakan faktor-faktor yang dapat berkontribusi bayi memiliki berat lahir rendah pertumbuhan ( Ketut Mendri \& Sarwo Prayogi)

Data yang diperoleh dari RS Kencana Serang Banten Tahun 2019 didapatkan pasien neonatal baru sebanyak 326 melalui rujukan dan non rujukan dengan angka kejadian BBLR sebesar 11,4\% (Profil RS Kencana Serang Banten Tahun 2019). Berdasarkan latar belakang yang diuraikan diatas maka penulis tertarik untuk melakukan penelitian tentang Determinan kejadian Bayi Berat Lahir Rendah (BBLR) di RS Kencana Serang Banten Tahun 2019 .

\section{METODE}

Rancangan penelitian menggunakan Cross Sectional, Populasi dalam penelitian ini adalah ibu yang melahirkan bayi sebanyak 276 responden, sampel sebanyak 179 responden yang memenuhi kriteria inklusi dan ekslusi yang telah ditetapkan, pengambilan sampel menggunakan teknik Systematic Random Sampling, Jenis data dalam penelitian ini adalah sekunder yang diperoleh dari buku register persalinan dan rekam medik dalam kurun waktu 1 Januari -31 Desember 2019. Instrumen dalam penelitian ini menggunakan check list, analisis data meliputi analisis univariate, bivariate dan multivariate.

\section{HASIL}

Dari hasil penelitian didapatkan responden yang tidak BBLR sebanyak 136 (76\%) dan yang BBLR sebanyak 43 (24\%) dari total 179 (100\%), dengan berat lahir terendah 1950 gram dan berat lahir terbesar adalah 2410 gram. Jumlah umur ibu tidak beresiko 20 - 35 tahun sebanyak 128 (71,5\%) lebih banyak dibandingkan dengan umur ibu beresiko $<20$ dan $>35$ tahun yaitu 51 (28,5\%) dari total 179 (100\%). Usia terendah adalah 18 tahun, usia tertinggi adalah 42 tahun, dengan usia ibu bersalin terbanyak yaitu usia 23 tahun serta rata-rata usia bersalin adalah 27 tahun. Jumlah primipara sebanyak 78 (43,6\%) lebih sedikit dibandingkan dengan multipara yaitu $101(56,4 \%)$ dari total 179 (100\%). Primipara merupakan paritas terbanyak, dan paritas terbanyak adalah 3 . Jumlah ibu yang berpendidikan tinggi sebanyak 161 (89,9\%) lebih banyak dibandingkan dengan ibu yang berpendidikan rendah yaitu 18 (10,1\%) dari total 179 (100\%). Pendidikan terendah adalah SMP, pendidikan tertinggi adalah S1 dan 
mayoritas ibu berpendidikan SMA. bahwa jumlah ibu yang tidak bekerja sebanyak 131 $(73,2 \%)$ lebih banyak dibandingkan dengan jumlah ibu yang bekerja yaitu $48(26,8 \%)$ dari total 179 (100\%). Mayoritas ibu bekerja sebagai karyawan swasta. Dari hasil penelitian menunjukan bahwa ibu yang melakukan kunjungan ANC dengan lengkap sebanyak 148 $(82,7 \%)$ lebih banyak dibandingkan ibu yang kunjungan ANC nya tidak lengkap yaitu 31 $(17,3) \%$ dari total yaitu 179 (100\%). Rata-rata ibu yang kunjungan ANC nya tidak lengkap adalah di K1 (Kunjungan pertama di Trimester 1). (Tabel 1)

Hasil penelitian didapatkan umur responden yang berisiko dengan kejadian BBLR sebanyak 27 (52,9\%) dibandingkan dengan usia responden yang tidak berisiko dengan kejadian BBLR yakni sebanyak 16 (12,5\%). Hasil uji statistik dengan Chi Square diperoleh nilai $\mathrm{p}=$ 0,000 berarti $p<\alpha(0,05)$, hipotesis terbukti maka dapat disimpulkan ada hubungan antara umur ibu dengan kejadian BBLR. Dari hasil analisis diperoleh lebih lanjut diperoleh nilai OR $=7,8(95 \% \mathrm{Cl}: 3,68-16,8)$ artinya umur responden yang berisiko berpeluang 7,8 kali untuk terjadinya BBLR dari pada umur ibu yang tidak beresiko.

Responden multipara dengan kejadian BBLR sebanyak 26 (25,7\%) dibandingkan dengan primipara dengan kejadian BBLR yakni sebanyak 17 (21,8\%). Hasil uji statistik dengan
Chi Square diperoleh nilai $p=0,540$ berarti $p>\alpha$ $(0,05)$, maka dapat disimpulkan tidak ada hubungan antara paritas dengan kejadian BBLR . Responden yang berpendidikan rendah dengan kejadian BBLR sebanyak 13 (72,2\%) dibandingkan dengan responden yang berpendidikan tinggi dengan kejadian BBLR yakni sebanyak 30 (18,6\%). Hasil uji statistik dengan Chi Square diperoleh nilai $p=0,000$ berarti $p<\alpha(0,05)$, hipotesis terbukti maka dapat disimpulkan ada hubungan antara pendidikan dengan kejadian BBLR, diperoleh nilai $\mathrm{OR}=11,3$ artinya responden berpendidikan rendah berpeluang 11,3 kali untuk terjadinya BBLR dari pada responden yang berpendidikan tinggi. Responden yang bekerja dengan kejadian BBLR sebanyak 19 (39,6\%) dibandingkan dengan responden yang tidak bekerja dengan kejadian BBLR yakni sebanyak 24 (18,3\%). Hasil uji statistik dengan Chi Square diperoleh nilai $p$ $=0,004$ berarti $p<\alpha(0,05)$, hipotesis terbukti maka dapat disimpulkan ada hubungan yang signifikan antara pekerjaan dengan kejadian $B B L R$, diperoleh nilai $O R=2,9$ artinya responden yang bekerja berpeluang 2,9 kali untuk terjadinya BBLR dari pada responden yang tidak bekerja. Responden yang kunjungan ANC tidak lengkap dengan kejadian BBLR sebanyak 25 $(80,6 \%)$ dibandingkan dengan responden yang kunjungan ANC lengkap kejadian BBLR yakni sebanyak 18 (12,2\%). Hasil uji statistik dengan Chi Square diperoleh nilai $p=0,000$ berarti $p<\alpha$ 
Jurnal Bidang Ilmu Kesehatan

$(0,05)$, hipotesis terbukti maka dapat disimpulkan ada hubungan antara kunjungan ANC dengan kejadian BBLR, diperoleh nilai $\mathrm{OR}=$ 30 artinya responden yang kunjungan ANC tidak lengkap berpeluang 30 kali untuk terjadinya BBLR dari pada responden kunjungan ANC lengkap.

Variabel yang paling dominan berhubungan dengan kejadian BBLR adalah kunjungan ANC dengan nilai OR 18,4, artinya ibu dengan kunjungan ANC tidak teratur mempunyai peluang 18,4 kali lebih besar untuk melahirkan BBLR dibandingkan dengan ibu yang kunjungan ANC teratur

Primipara

Multipara

3 Pendidikan

Tinggi

161

Rendah

4 Pekerjaan

Tidak bekerja

131

48

73,2

Bekerja

5 Kunjungan

ANC

Lengkap 148

82,7

Tidak lengkap

Tabel 1

Kejadian Bayi Berat Lahir Rendah

\begin{tabular}{cccc}
\hline No & $\begin{array}{c}\text { Berat Badan } \\
\text { Lahir }\end{array}$ & Jumlah & $\begin{array}{c}\text { Persentase } \\
\text { (\%) }\end{array}$ \\
\hline 1. & Tidak BBLR & 136 & 76 \\
2. & BBLR & 43 & 24 \\
& Jumlah & $\mathbf{1 7 9}$ & $\mathbf{1 0 0 , 0}$ \\
\hline
\end{tabular}

Tabel 2

Variabel independen kejadian BBLR

\begin{tabular}{llcc}
\hline No & Variabel & Frekuensi & $\%$ \\
\hline 1 & Usia & & \\
& Tidak berisiko & 128 & 71,5 \\
& Berisiko & 51 & 28,5 \\
2 & Paritas & & \\
\hline
\end{tabular}


Tabel 3

Kejadian BBLR dengan usia, paritas, pendidikan, pekerjaan dan kunjungan ANC

\begin{tabular}{|c|c|c|c|c|c|c|c|c|}
\hline \multirow{3}{*}{ Variabel } & \multicolumn{4}{|c|}{ Berat Badan Lahir } & \multirow{2}{*}{\multicolumn{2}{|c|}{ Total }} & \multirow{3}{*}{$\begin{array}{c}\mathrm{P} \\
\text { Value }\end{array}$} & \multirow{3}{*}{ OR (Cl 95\%) } \\
\hline & \multicolumn{2}{|c|}{ BBLR } & \multicolumn{2}{|c|}{ Tidak BBLR } & & & & \\
\hline & $n$ & $\%$ & $\mathrm{n}$ & $\%$ & n & $\%$ & & \\
\hline \multicolumn{9}{|l|}{ Usia } \\
\hline $\begin{array}{l}\text { Beresiko (< } 20 \text { dan } \\
>35 \text { tahun) }\end{array}$ & 27 & 52,9 & 24 & 47,1 & 51 & 100 & 0,000 & 7,87 \\
\hline $\begin{array}{l}\text { Tidak Beresiko } \\
\text { ( } 20-35 \text { tahun }\end{array}$ & 16 & 12,5 & 112 & 87,5 & 128 & 100 & & $(3,68-16,8)$ \\
\hline \multicolumn{9}{|l|}{ Paritas } \\
\hline Multipara & 26 & 25,7 & 75 & 74,3 & 101 & 100 & 0,540 & 1,244 \\
\hline Primipara & 17 & 21,8 & 61 & 78,2 & 78 & 100 & & $(0,61-2,50)$ \\
\hline \multicolumn{9}{|l|}{ Pendidikan } \\
\hline Rendah & 13 & 72,2 & 5 & 27,8 & 18 & 100 & 0,000 & 11,35 \\
\hline Tinggi & 30 & 18,6 & 131 & 81,4 & 161 & 100 & & $(3,76-34,28)$ \\
\hline \multicolumn{9}{|l|}{ Pekerjaan } \\
\hline Ya & 19 & 39,6 & 29 & 60,4 & 48 & 100 & 0,004 & 2,91 \\
\hline Tidak & 24 & 18,3 & 107 & 81,7 & 131 & 100 & & $(1,41-6,05)$ \\
\hline \multicolumn{9}{|l|}{ Kunjungan ANC } \\
\hline Tidak Lengkap & 25 & 80,6 & 6 & 19,4 & 31 & 100 & 0,000 & 30,09 \\
\hline Lengkap & 18 & 12,2 & 130 & 87,8 & 148 & 100 & & $(10,8-83,3)$ \\
\hline
\end{tabular}


Jurnal Bidang Ilmu Kesehatan

Tabel 4

Permodelan Multivariat Akhir

\begin{tabular}{ccc}
\hline Variabel & Pvalue & OR \\
\hline Umur & 0,005 & 4,102 \\
Pendidikan & 0,021 & 5,186 \\
Pekerjaan & 0,023 & 3,3031 \\
Kunjungan ANC & 0,000 & 18,449 \\
\hline
\end{tabular}




\section{PEMBAHASAN}

Hasil penelitian didapatkan bahwa dari 179 responden yaitu 43 (24\%) BBLR dan 136 (76\%) tidak BBLR. Angka kejadian BBLR di RS Kencana Serang Banten tahun 2019 yakni 24\% lebih tinggi dibandingkan di Indonesia sebesar 10,2\% (Kemenkes Tahun 2014), kejadian tersebut dipengaruhi oleh umur, pendidikan, pekerjaan dan kunjungan ANC., hal ini sejalan dengan penelitian Eka Titin Oktaviani (2016) mengatakan bahwa dari 589 ibu bersalin di RSUD Abdoel Moeloek tahun 2016, terdapat $161(27,3 \%)$ ibu melahirkan bayi BBLR dan 428 $(72,7 \%)$ ibu yang melahirkan bayi tidak BBLR .

Dari hasil tersebut sesuai dengan beberapa penelitian dan teori yang ada yaitu Berat lahir bayi yang tidak normal akan memberikan risiko pada ibu dan bayi . BBLR atau berat lahir < 2.500 gram banyak dihubungkan dengan meningkatnya risiko kesakitan dan kematian bayi, terlambatnya pertumbuhan dan perkembangan kognitif, dan selanjutnya menderita penyakit kronik dikemudian hari. BBLR mempunyai risiko kematian neonatal hampir 40 kali lebih besar dibandingkan dengan bayi dengan berat lahir normal (Fikawati, dkk, 2012 ) .

Menurut Atikah dan Cahyo (2010) penyebab terjadinya BBLR secara umum bersifat multifaktorial, sehingga kadang mengalami kesulitan untuk melakukan tindakan pencegahan. Namun, penyebab terbanyak terjadinya bayi BBLR adalah kelahiran prematur. Semakin muda usia kehamilan semakin besar risiko jangka pendek dan jangka panjang dapat terjadi .

Atikah Cahyo (2010) juga mengatakan bahwa ada beberapa usaha untuk menurunkan kejadian BBLR di masyarakat, yaitu dengan melakukan beberapa upaya sebagai berikut: mendorong perawatan kesehatan remaja putri, mengusahakan semua ibu hamil mendapatkan perawatan antenatal yang komperhensif, memperbaiki status gizi ibu hamil, dengan mengkonsumsi makanan yang lebih sering atau lebih banyak, dan lebih diutamakan makanan yang mengandung nutrisi yang memadai, menghentikan kebiasaan merokok, menggunakan obat-obatan terlarang dan alkohol pada ibu hamil, meningkatkan pemeriksaan kehamilan secara berkala minimal 4 kali selama kurun kehamilan dan dimulai sejak umur kehamilan muda .

Hasil penelitian didapatkan ada hubungan antara umur ibu dengan kejadian BBLR . Hasil penelitian ini sejalan dengan hasil penelitian Marlenywati, dkk (2015) tentang faktor-faktor yang mempengaruhi kejadian BBLR di RSUD dr. Soedarso Pontianak dengan hasil analisis hubungan antara usia ibu dengan BBLR diperoleh bahwa proporsi ibu usia $<20$ tahun dan > 35 tahun melahirkan BBLR 15 (33,3\%), lebih besar daripada ibu usia 20 - 35 tahun . 
Hasil uji statistik diperoleh nilai $p=0,000$ maka dapat disimpulkan ada hubungan antara usia ibu dengan BBLR . Hasil analisis diperoleh nilai $\mathrm{OR}=5,333$, artinya ibu usia $<20$ tahun dan $>35$ tahun memiliki risiko 5,333 kali melahirkan BBLR dibanding ibu usia 20-35 tahun .

Menurut penelitian yang dilakukan oleh Felix, dkk (2008) menyatakan bahwa usia ibu lebih dari 35 tahun 5 kali lebih berisiko melahirkan bayi BBLR dibandingkan dengan usia ibu kurang dari 20 tahun di Rumah Sakit Immanuel Bandung . Hal ini disebabkan karena jaringan alat reproduksi dan fungsi fisiologis jalan lahirnya telah mengalami proses kemunduran sehingga dapat menimbulkan kelahiran BBLR . Umur adalah usia individu yang terhitung mulai saat dilahirkan sampai saat berulang (Alma, Buchari. 2013). Umur dihitung dalam tahun dengan pembulatan ke bawah atau umur pada waktu ulang tahun yang terakhir berdasarkan pada kalender masehi (Wahyuni, Sri. 2013) . Umur yang produktif adalah merupakan umur yang berada pada usia $20-35$ tahun. Berdasarkan hasil penelitian, dapat dilihat bahwa $71,5 \%$ berada pada usia produktif . Pada masa reproduksi, manusia yang sehat adalah manusia dalam ukuran umur 20 tahun sampai 35 tahun .

Usia ini tidak beresiko, merupakan usia yang aman dan baik untuk proses hamil dan bersalin . Jika kehamilan terjadi pada usia < 20 tahun, hal ini membahayakan bagi pertumbuhan janin dikarenakan alat reproduksi ibu yang hamil belum matang (Manuaba, 2010) . Usia ibu saat hamil merupakan salah satu faktor yang sangat berpengaruh terhadap proses kehamilan, kesehatan janin di dalam kandungan, dan kelancaran proses kelahiran . Usia ideal untuk menjalani suatu kehamilan adalah antara 20-35 tahun. Sedangkan puncak kesuburan terjadi pada umur 20-29 tahun. Peluang kehamilan pada usia 20-29 tahun adalah 95\%, setelah memasuki umur 30 tahun, peluang untuk hamil menurun sampai 90\%, pada usia 40 tahun, kesempatan ibu untuk hamil $40 \%$ dan setelah usia 40 tahun peluang untuk hamil hanya $10 \%$.

Pada rentang usia 20-29 tahun kondisi fisik wanita dalam keadaan prima . Rahim sudah mampu menjalankan fungsinya dengan baik. Secara mental, wanita pada usia rentang ini sangat siap menjalani kehamilan (Anonimus, 2010) .

Bertambahnya usia akan semakin meningkatkan pula risiko hipertensi selama kehamilan yang juga merupakan faktor predisposisi terjadinya Berat Bayi Lahir Rendah (BBLR), beberapa penelitian menunjukan bahwa tekanan darah tinggi selama kehamilan lebih mudah terjadi pada ibu hamil berusia lebih dari 35 tahun (Deri dan Yasid, 2013) .

Hasil penelitian didapatkan tidak ada hubungan yang signifikan antara paritas dengan kejadian BBLR . Hasil penelitian ini sejalan 
dengan hasil penelitian Eka Titin Oktaviani (2016) tentang hubungan usia, paritas dan kehamilan ganda dengan kejadian BBLR di RSUD Abdoel Moeloek Provinsi Lampung tahun 2016 dengan hasil uji statistik menggunakan chi square di dapatkan p-value 0,628 $>\alpha 0,05$ ,artinya tidak terdapat hubungan antara paritas ibu dengan kejadian BBLR di RSUD Abdoel Moeloek tahun 2016 .

Menurut Sandra Surya, dkk (2012) mengatakan bahwa kejadian BBLR pada ibu dengan paritas pertama disebabkan oleh masih minimnya pengalaman dan pengetahuan ibu hamil dalam menangani kehamilannya .

Paritas merupakan banyaknya kelahiran yang mampu hidup di luar rahim. Paritas yang beresiko adalah paritas yang interval kurang dari 2 tahun dan jumlah kelahiran lebih dari 4 kali. Kelebihan dalam proses kelahiran, dapat mempengaruhi proses reproduksi sehingga berdampak pada permasalahan kesehatan bagi ibu dan bayi . Salah satu dampaknya, memungkinkan terjadinya kejadian BBLR (Manuaba, 2010) .

Menurut teori Amiruddin (2014), yang menyatakan paritas 1 dan lebih dari 4 dianggap beresiko terhadap BBLR, hal ini terkait bahwa pada paritas 1 organ reproduksi belum cukup optimal untuk berkontraksi pada saat kehamilan, sementara paritas lebih dari 4 menyebabkan rahim mengalami kontraksi yang berlebihan dan fisiologi rahim yang kurang optimal untuk pertumbuhan janin .

Pernyataan tentang paritas tidak berpengaruh terhadap kejadian BBLR tidak sejalan dengan penelitian yang dilakukan Endriana (2012) dimana paritas berhubungan dengan BBLR hal ini di sebabkan kebanyakan pasangan suami istri tidak mau melakukan program KB (keluarga berencana) mereka beranggapan bahwa anak adalah rejeki dari Tuhan Yang Maha Esa sehingga banyak ibu yang melahirkan sampai 4 kali di usia yang tidak muda, hal ini sangat beresiko dan menyebabkan bayi lahir premature, BBLR, bahkan kematian janin karena kurangnya pengetahuan atau edukasi. Menurut peneliti paritas atau jumlah anak tidak mempengaruhi kejadian BBLR karena semakin banyak jumlah anak yang dilahirkan maka semakin banyak mendapat pengalaman dalam menjaga dan merawat proses kehamilan dan keadaan rahim pada paritas yang tinggi akan semakin elastis sehingga janin yang dikandung akan mendapat tempat yang lebih luas untuk bertumbuh dan berkembang maka akan mempengaruhi berat badan janin .

Hasil penelitian didapatkan ada hubungan antara pendidikan dengan kejadian BBLR . Hasil penelitian ini sejalan dengan hasil penelitian Sandra Surya, dkk (2012) faktorfaktor risiko kejadian BBLR di Wilayah Kerja UPT 
Kesmas Gianyar II Tahun 2012 mengatakan bahwa ada hubungan antara pendidikan dengan kejadian BBLR. Ibu hamil dengan tingkat pendidikan rendah memiliki risiko 19.190 kali lebih besar untuk melahirkan BBLR dibandingkan ibu hamil dengan tingkat pendidikan tinggi . Secara konsisten penelitian menunjukkan bahwa tingkat pendidikan yang dimiliki ibu mempunyai pengaruh kuat pada perilaku reproduksi, kelahiran, kematian anak dan bayi, kesakitan, dan sikap serta kesadaran atas kesehatan keluarga. Latar belakang pendidikan itu mempengaruhi sikapnya dalam pemilihan pelayanan kesehatan dan pola konsumsi makan yang berhubungan juga dengan peningkatan berat badan ibu semasa hamil yang pada saatnya akan mempengaruhi kejadian BBLR . Ibu yang berpendidikan rendah sulit untuk menerima inovasi dan sebagian besar kurang mengetahui pentingnya perawatan pra kelahiran . Disamping itu juga mempunyai keterbatasan mendapatkan pelayanan antenatal yang adekuat, keterbatasan mengkonsumsi makanan yang bergizi selama hamil. Kesemuanya ini akan mengganggu kesehatan ibu dan janin, bahkan sering mengalami keguguran atau lahir mati (Varney, 2003) Menurut Megawangi (1999) seperti dikutip Yustina (2007), mengatakan bahwa banyak studi membuktikan kaitan positif antara pendidikan perempuan dan tingkat produktivitasnya, rasa percaya diri, rendahnya angka kematian bayi, perbaikan status gizi balita dan lain-lain . Pendidikan banyak menentukan sikap dan tindakan dalam menghadapi berbagai masalah termasuk pengaturan makanan bagi ibu hamil untuk mencegah timbulnya bayi berat lahir rendah (BBLR) .

Hasil penelitian didapatkan ada hubungan antara pekerjaan dengan kejadian BBLR . Hasil penelitian ini sejalan dengan hasil penelitian Oktovina (2011), dalam penelitianya di RSUD Sulawesi Tenggara menunjukan bahwa ibu yang bekerja 3,1 kali berisiko melahirkan bayi berat lahir rendah .

Penelitian Ferrer (2009) menyatakan bahwa persalinan prematur dan BBLR dapat terjadi pada wanita yang bekerja terus menerus selama kehamilan, terutama bila pekerjaan tersebut memerlukan kerja fisik atau waktu yang lama. Keadaan ini dapat mempengaruhi pertumbuhan dan perkembangan serta kesejahteraan janin yang dikandungnya . Menurut Depkes RI (2006) ibu hamil perlu istirahat yang cukup, menghindari pekerjaan yang melelahkan dan mengangkat benda yang berat .

Menurut Notoatmodjo (2012), ibu yang sibuk bekerja terutama yang melakukan pekerjaan fisik memiliki sedikit waktu untuk memperoleh informasi berkaitan dengan kondisi kesehatan . Ibu hamil yang mengambil 
pekerjaan berat dan melelahkan dapat mengganggu kondisi kesehatan ibu dan kandungannya yang berdampak pada pertumbuhan dan perkembangan janin dalam kandungan yang menyebabkan bayi berat lahir rendah (Proverawati,2010) dengan kata lain Ibu yang tidak bekerja dapat melakukan ANC dengan teratur karena ibu memiliki waktu lebih banyak dibandingkan dengan ibu yang bekerja . Pekerjaan berat semasa hamil dapat menyebabkan risiko bayi dengan berat badan lahir rendah. Beban kerja fisik berat bagi ibu hamil adalah ibu membantu suami mereka bekerja di sawah atau kebun. Pada masa hamil, asupan gizi seorang ibu akan bertambah, ditambah seorang ibu hamil bekerja berat, maka asupan energi yang dibutuhkan lebih banyak. Seorang ibu hamil bekerja dan asupan energinya tidak tercukupi maka akan berakibat pada kejadian BBLR, karena energi merupakan faktor gizi paling penting jika dikaitkan dengan BBLR (Arisman, 2007) .

Hasil penelitian didapatkan ada hubungan antara kunjungan ANC dengan kejadian BBLR . Hasil penelitian ini sesuai dengan hasil penelitian Ribka Yulia (2016) tentang hubungan pemeriksaan ANC dengan kejadian BBLR di Wilayah Kerja RSUD Tobelo, yaitu terdapat hubungan antara pemeriksaan ANC dengan kejadian BBLR dengan nilai $p$ value 0,001 .
Hasil penelitian ini juga sejalan dengan hasil penelitian Nurhayani, dkk ( 2015) bahwa ibu yang melahirkan BBLR lebih sedikit melakukan ANC yang lengkap daripada ibu yang melahirkan bayi normal dengan nilai $p$ value 0,026

Penelitian fitrah Ernawati, dkk (2011) dengan judul Hubungan Antenatal Care dengan Berat Badan lahir bayi di Indonesia (analisis lanjut data Riskesdas 2010) hasilnya adalah kunjungan ANC lebih dari 4 kali mempunyai peluang untuk tidak melahirkan anak BBLR sebesar 1,8 kali dibandingkan dengan ibu yang melakukan ANC kurang dari 4 kali, hasil tersebut juga sejalan dengan hasil penelitian in $\mathrm{i}$.

Dalam kehamilan pemeriksaan dilakukan paling sedikit 4 kali selama kehamilan yaitu 1 kali pada usia kandungan sebelum 3 bulan, 1 kali usia kandungan 4-6 bulan dan 2 kali pada usia kandungan 7-9 bulan (Kementerian Kesehatan, 2010) .

Variabel dominan yang berhubungan dengan kejadian BBLR dalam penelitian ini adalah kunjungan ANC. Ante Natal Care (ANC) adalah pelayanan kesehatan yang diberikan oleh tenaga kesehatan untuk ibu selama kehamilannya dan dilaksanakan sesuai dengan Standar Pelayanan Kebidanan (SPK) . Standar pelayanan ini dianjurkan guna menjamin perlindungan terhadap ibu atau janin, deteksi 
factor risiko dan pencegahan serta penanganan dini komplikasi kehamilan .

Kunjungan ANC merupakan indikator penting dalam meningkatkan kewaspadaan dan pemantauan kesehatan gizi ibu selama hamil serta janin. Saat ANC, ibu akan diberikan standar pelayanan ANC seperti penjelasan tanda komplikasi, pemeriksaan tekanan darah, gizi ibu, dan pendeteksian dini penyulit sehingga berpengaruh terhadap berat bayi yang akan dilahirkan (Adriaansz G, 2010)

\section{SIMPULAN}

Kejadian BBLR di RS Kencana Serang Banten Tahun 2019 sebesar 24\%, dengan berat lahir terendah 1950 gram dan berat lahir terbesar adalah 2410 gram. Variabel yang berhubungan signifikan dengan kejadian BBLR adalah umur, pendidikan, pekerjaan dan kunjungan ANC. Variabel yang dominan berhubungan dengan kejadian BBLR adalah kunjungan ANC dengan $\mathrm{OR}=18,4$.

\section{DAFTAR PUSTAKA}

Alimul Hidayat, A Aziz. 2007. Metode Penelitin Keperawatan dan Teknik Analisis Data. Jakarta: Salemba Medika Adriaansz G(2010). Asuhan antenatal. Dalam: Saifuddin $A B, \quad$ Rachimhadhi $T$, Winkjosastro GH. Ilmu Kebidanan
Sarwono Prawirohardjo. Ed 4, Jakarta : PT Bina Pustaka Sarwono Prawirohardjo.

A.Wawan, Dewi. 2011. Teori \& Pengukuran Pengetahuan, Sikap, Dan Perilaku Manusia. Yogyakarta: Nuha Medika

Anonymous. Neonatologi. Jakarta: Badan penerbit IDAI; 2010.

Atikah, Cahyo, 2010, Berat Badan Lahir Rendah, Yogyakarta: Fitramaya.

Arisman. (2007). Gizi dalam Daur Kehidupan.Jakarta: EGC

Amiruddin R, Hasmi. Determinan Kesehatan Ibu dan Anak. Jakarta: CV Trans Info Media; 2014.

Alma, Buchari. 2013. Manajemen Pemasaran dan Pemasaran Jasa. Bandung: Alfabeta

Budiman, A Riyanto, J Juhaeriah dkk.Faktor ibu yang berhubungan denganberat badan bayi lahir di puskesmas Garuda tahun 2010. Jurnal KesehatanKartika 2011.

Bambang, dkk. Hubungan Antara Usia Ibu Dan Paritas dengan Kejadian Berat badan lahir rendah (BBLR) Di RSU Dr. Saiful Anwar Malang. 2011 [Diakses tanggal 3 Maret 2020]. Didapat dari: http://old.fk.ub.ac.id/artikel/id/filedownl 
Jurnal Bidang Ilmu Kesehatan

oad/ kebidanan/ MAJALAH\% 20KHOIROTUL\% 20HABIBAH.pdf

BKKBN. 2008. Remaja dan SPN (Seks Pranikah).(Diakses tanggal 22 Oktober 2020).

Depkes RI. 2009. Pedoman Pelayanan Kesehatan Bayi Berat Lahir Rendah (BBLR) dengan Perawatan Metode Kanguru di Rumah Sakit dan Jejaringnya. Jakarta.

Depkes RI. 2013. Riset Kesehata Dasar (RISKESDAS). Jakarta: Litbang Departemen Kesehatan

Depkes RI. 2006.Analisis Situasi Gizi dan Kesehatan Masyarakat. Jakarta: Depkes.

Deri Rizki Anggarani dan Yazid Subakti. 2013. Kupas Tuntas Seputar Kehamilan. Agro Media Pustaka. Jakarta Selatan. http://books.google.co.id/4 2020)

Dwinda R Octa, dkk. (2014). Buku Ajar Asuhan Kebidanan Neonatus, Bayi/Balita dan Anak Prasekolah Untuk Para Bidan, Yogyakarta : Deepublish.

Dewi, Endriana. 2012.Hubungan Umur dan Paritas Ibu denganBerat Bayi Lahir di RB Citra Insani Semarang. Fakultas IImu Keperawatan dan Kesehatan Universitas Muhammadiyah Semarang.

Elizabeth, Hurlock. (1998). Perkembangan Anak Jilid I.Jakarta : Erlangga
Eka Titin. Hubungan usia, paritas dan kehamilan ganda dengan kejadian BBLR di RSUD Abdoel Moeloek Lampung Tahun 2016. http://isjd.pdii.lipi.go.id[di akses pada tanggal 4 Nopember 2019]

Felix, dkk. Hubungan antara karakteristik ibu Hamil dengan Kejadian Bayi Berat Badan Lahir Rendah di Rumah sakit Immanuel bandung. JKM Vol.10No2. 2008 [Diakses tanggal 5 Maret 2020]. Didapat

dari:http://repository.maranatha.edu/213 5/1/0610125AbstractTOC.pdf

Fitrah Ernawati, dkk. Hubungan Antenatal Care dengan Berat Badan lahir bayi di Indonesia (analisis lanjut data Riskesdas 2010) 2011. http://isjd.pdii.lipi.go.id[di akses pada tanggal 4 Nopember 2019]

Fikawati, dkk. Status gizi ibu hamil dan Berat lahir bayi pada kelompok vegetarian. http://isjd.pdii.lipi.go.id[di akses pada tanggal 4 Nopember 2019]

Fatimah Anggi, dkk. Faktor-faktor yang berhubungan dengan kejadian BBLR di Wilayah kerja Puskesmas Bangetayu Kota Semarang Tahun 2016 . http://isjd.pdii.lipi.go.id[di akses pada tanggal 4 Nopember 2019]

Gebregzabiherher, Y., Haftu, A., Weldemariam, S., \& Gebrehiwet H. (2017). The Prevalence and Risk Factors for Low 
Birth Weight among Term Newborns in Adwa General Hospital, Northern Ethiopia. Obstetrics and Gynecology International,1-7

Hastono, Sutanto Priyo. (2007). Modul Analisis Data. Fakultas Kesehatan Masyarakat Universitas Indonesia

Icemi Sukarni K, \& Wahyu P. (2013). Buku Ajar Keperawatan Maternitas dielngkapi Contoh Askep.Yogyakarta: Nuha Medika.

Kosim M. Sholeh. 2008. Buku ajar neonatologi. Edisi pertama.IDAI.Jakarta

Kemenkes RI. Propil Kesehatan Indonesia Tahun 2014. Jakarta: Kementerian Kesehatan Republik Indonesia; 2015.

Khatun, S. Dan Rahman, M., 2008. SocioEconomic Determinants of Low Birth Weight in Bangladesh : A Multivariate Approach.

Maryam, S. 2016. Gizi dalam kesehatan reproduksi. Jakarta. Penerbit Salmeba Medika

M. Sholeh kosim, dkk. Buku Ajar Neonatologi. Ikatan Dokter Anak Indonesia. Jakarta . 2012

Mendri, Ni Ketut \& Prayogi, Sarwo A. 2017. Asuhan Keperawatan Pada Anak Sakit dan Bayi Resiko Tinggi.Yogyakarta: Pustaka Baru press
Meadow, R. \& Newell, S. (2005). Lecture Notes Pediatrika. Jakarta: Erlangga

Marlenywati, dkk. Faktor-faktor yang mempengaruhi kejadian BBLR di RSUD Soedarso Pontianak Tahun 2012. http://isjd.pdii.lipi.go.id[di akses pada tanggal 4 Nopember 2019]

Manuaba IBG MI, Manuaba I,. Pengantar Kuliah Obstetri. EGC. 2010:810-21.

Notoatmodjo, S. (2003). Pendidikan kesehatan dan ilmu perilaku. Jakarta : Rineka Cipta.

2010. Metodologi Penelitian Kesehatan. Jakarta: Rineka Cipta 2012. Promosi Kesehatan dan Ilmu Perilaku.Jakarta :Rineka Cipta. .2014. IImu Perilaku Kesehatan. Jakarta: Rineka Cipta

Nursalam,Dkk.(2005). Asuhan Keperawatan Bayi dan Anak, Jakarta: Salemba Medika Nurhayani Fatimah, dkk (2015) Hubungan antenatal care dengan kejadian BBLR pada ibu aterm di RSUP Dr. M.Djamil Padang Tahun 2015. http://isjd.pdii.lipi.go.id[di akses pada tanggal 4 Nopember 2019]

Palutturi, S. Nurhayani. Nurhamsa M. (2006). Determinan Kinerja Bidan Di Puskesmas Tahun 2006. Makassar : Universitas Hasanuddin. Jurnal Manajemen 
Jurnal Bidang Ilmu Kesehatan

Pelayanan Kesehatan Vol.10 No.04

Desember 2007

Proverawati, A. 2010. BBLR (Berat Badan Lahir Rendah). NuhaMedika, Yogyakarta

Profil RS X Serang Banten Tahun 2019

Proverawati, A. 2010. BBLR (Berat Badan Lahir Rendah). NuhaMedika, Yogyakarta

Pantiawati, Ika . 2010 . Bayi dengan BBLR. Yogjakarta

Prawirohardjo, Sarwono. 2007. Ilmu Kandungan Edisi 2 Jilid 4. Jakarta: YBP-SP.

Rukiyah Y, dan Yulianti lia, 2010. Asuhan Kebidanan IV. Trans infoMedia. Jakarta

Rukmono P. (2013). Neonatologipraktis. Bandar Lampung: AURA

Ribka Yulia R, dkk (2016) Hubungan pemeriksaan Antenatal Care (ANC) dengan kejadian BBLR di Wil Kerja RSUD Tobelo Tahun 2016, http://isjd.pdii.lipi.go.id[di akses pada tanggal 4 Nopember 2019]

Ratna, Megawangi. 1999. MembiarkanBerbeda: Sudut Pandang Baru Tentang Relasi Gender. Bandung: Mizan

Sandra Surya, dkk. Faktor-faktor risiko kejadian BBLR di Wilayah Kerja UPT Kesmas Gianyar II Tahun 2012. http://isjd.pdii.lipi.go.id[di akses pada tanggal 4 Nopember 2019]

Saifuddin A B, dkk. 2002. Pelayanan Kesehatan maternal dan neonatal.Yayasan bina pustaka sarwono prawirohardjo. Jakarta

Salmah,dkk.2006.Asuhan

Kebidanan

Antenatal.Jakarta:EGC

Varney, Helen. 2004.IImu Kebidanan (Varney's Midwife '3rded). Bandung :Sekeloa Publisher

World Health Organization (WHO). 2007. Development of a strategy towards promoting optimal fetal growth.

WHO. Childhood Stunting: Context, Causes and Consequences. Maternaland Child Nutrition. 2013.

WHO, World Health Organization. 2013. Trend in Maternal Mortality: 1999 to 2013. Geneva: WHO, UNICEF, UNFPA, and The World Bank.2013

WHO. Optimal Feeding Of Low Birthweigh Infants in Low-And Middle Income Countries. Geneva: World Health Organization; 2011.

Wiknjosastro H. 2007. Ilmu Kebidanan. Jakarta : Yayasan Bina Pustaka Sarwono Prawirohardjo 
Jurnal Bidang Ilmu Kesehatan

Wahyuni, S., \& Dwi, P. (2013). Pengalaman Ibu dalam Melakukan Perawatan Metode Kanguru

Yustina, I, 2007. Upaya Strategis menurunkan AKI dan AKB. Jurnal wawasan.
Zaenab dan Juharno. (2006).Beberapa Faktor Risiko Kejadian BBLR DiRumah Sakit Al Fatah Ambon Periode Januari Desember 